\title{
PENINGKATAN HASIL BELAJAR IPA MELALUI PENERAPAN METODE INKUIRI BERBANTUAN VIDEO INTERAKTIF PADA SISWA KELAS III SD
}

\author{
Cahya Murtiningsih', Henny Dewi Koeswati ${ }^{2}$,Sri Giarti ${ }^{3}$ \\ ${ }^{1}$ Pendidkan Guru Sekolah Dasar, UKSW Salatiga, 292013229@student.uksw.edu \\ ${ }^{2}$ Pendidkan Guru Sekolah Dasar, UKSW Salatiga, Dewi@staff.uksw.edu \\ ${ }^{3}$ Pendidkan Guru Sekolah Dasar, UKSW Salatiga,Sgiarty@gmail.com
}

\section{INFO ARTIKEL}

Riwayat Artikel:

Diterima: 26-03-2018

Disetujui: 09-04-2018

\section{Kata Kunci:}

Hasil Belajar

Metode Inkuiri

berbantuan Video

Intraktif

\begin{abstract}
ABSTRAK
Abstrak:. Penelitian ini bertujuan untuk melihat peningkatan hasil belajar IPA melalui penerapan metode inkuiri berbantuan video interaktif pada siswa kelas III SD. Jenis penelitian yang digunakan adalah penelitian tindakan kelas yang terdiri dari 2 siklus. Setidap siklus setiap siklus dilaksanakan melalui 3 tahapan yaitu perencanaan, pelaksanaan, dan refleksi. Subyek penelitian ini adalah seluruh siswa kelas III SD. Data penelitian ini diperoleh melalui observasi dan tes. Data tes hasil belajar siswa dianalisis berdasarkan persentase ketuntasan belajar secara individu dan klasikal kemudian dijabarkan secara deskriptif. Hasil penelitian menunjukkan adanya peningkatan persentase hasil belajar siswa pada siklus I dan siklus II. Hasil belajar yang diperoleh siswa kelas III SD mengalami peningkatan. Hal ini ditunjukkana danya hasil belajar siswa pada evaluasi mengacu pada kriteria keberhasilan yang sudah ditentukan yaitu 70. Nilai ratarata ketuntasan belajar siswa secara klasikal mengalami peningkatan sebesar $82 \%$ pada mata pelajaran IPA. Dengan rincian pra siklus ketuntasan $46 \%$ dari 18 siswa yang telah mencapai keberhasilan dengan rata-rata 68, siklus I menjasi 56\% dari 22 siswa yang telah mencapai keberhasilan dengan rata-rata 68 , dan menjadi $82 \%$ pada siklus II dari 32 siswa yang mencapai ketuntasan belajar dengan rata-rata 72. Berdasarkan hasil yang diperoleh dapat disimpulkan bahwa pembelajaran dengan menggunakan metode inkuiri berbantuan video interaktif dapat meningkatkan hasil bellajar siswa.
\end{abstract}

\begin{abstract}
: this study aims to see the improvement of science learning outcomes trought the aplications of inquiry learning method assisted interactive video in the third grade students of SD. Type of research used is clasroom acion research consisting of two cycles. Each cycles is implemented throught three stages of plannning, implementatio, and reflection. The subjects of this study were all students SD. The data of this study were obtained throught observation and test. The data of students' learning outcomes were analyzed based on the percentage of learning completeness individually an clasically then described descriptively. The result showed an increase in the percentage of student learning on SD. This is incated by the result of student learning on evaluation refers to succes criteria that have been determined that is 70 . The average grade of students' learning completeness in class has increased by $82 \%$ in science subjects. With pre-cycle completeness details if $44 \%$ off 18 students who have achieved succes with an average of $68 \%$, cycle I/ of 32 students who achieve mastery learning with an average of 72 . Assisted interactive video can improve student learning outcomes.
\end{abstract}

\section{A. LATAR BELAKANG}

Pembelajaran merupakan proses interaksi antara siswa dengan pendidik dan sumber belajar pada suatu lingkup lingkaran belajar (Undang-undang Republik Indonesia Nomor 20 Tahun 2003 Tentang Sistem Pendiikan Naional Pada Pasal 11). Sehingga pembelajaran adalah proses suatu usaha untuk membuat peserta didik belajar atau kegiatan untuk membelajarkan peserta didik sehingga dapat mencapai tujuan yang akan dicapai oleh peserta didik.
Pembelajaran dalam proses kegiatan belajar mengajar tidak lepas dari hasil belajar siswa.

Hasil belajar adalah perubahan yang terjadi pada diri siswa, baik yang menyangkut pada aspek kognitif, afektif, dan psikomotorik sebagai hasil dari kegiatan belajar (Susanto, 2015: 5). Sedangkan, menurut Wardani (2012: 12) hasil belajar adalah besarnya skor yang diperoleh melalui pengukuran pada proses belajar (non tes) dan pengukuran apda hasil belajar (tes). Berdasarkan uraian tersebut maka dapat disimpulkan bahwa hasil belajar merupakan perubahan yang terjadi pada siswa sebagai tingkat keberhasilan danlam 
mempelajari materi-materi yang ada disekolah melalui tes atau mengenal sejumlah materi pelajaran tertentu yang dapat dinyatakan dalam skor. Hasil belajar dalam proses pembelajaran merupakan salah satu faktor terpenting di dalam semua mata pelajaran, salah satunya adalah mata pelajaran IPA.

IPA dipandang sebagai cara mencari tahu tentang alam, untuk menguasai pengetahuan, fakta-fakta, konsekonse, prinsip-prinsip, proses penemuan, dan memiliki sikap ilmiah . menurut Trianto (2007: 102) IPA adalah suatu kumpulan teori yang sistematis, penerapanyya secara umum terbatas pada gejala-gejala alam, lahir dan berkembang melalui metode ilmiah seperti rasa ingin tahu, terbuka, jujur dan sebagainya. Sehingga untuk menumbuhkan sikap ilmiah pada peserta didik diperlukan suatu pembelajaran yang dapat memotivasi siswa untuk aktif.

Menurut Sudjana Rivai ( 2010: 2) ada beberapa alasan, mengapa media pelajaran dapat mempertinggi proses belajar siswa. alasan yang pertama berkenaan dengan taraf berpikir siswa mulai dari berpikir kongkret menuju ke berpikir abstrak.

Pada pelaksanaanya, IPA saat proses pembelajaran guru masih menodiminasi dan menjadi pusat perhatian selama proses pembelajaran (Teacher centered). Sehingga membuat siswa diam, pasif, mengobrol diluar konteks pembelajaran, mengantuk, dan bisan. Guru lebih sering menggunakan metode ceramah, tanya jawab, penugasan dalam suatu proses pembelajaran dan jarang menggunakan media, awalaupun terkadang digunakan dalam proses pembelajaran. Tetapi, tidak semua mata pelajaran guru menggunakan media.

Berdasarkan permaslahan tersebut untuk meningkatkan hasil belajar siswa kelas III SD, diperlukan upaya untuk mengatassi dalam pembelajaran IPA, upaya untuk mengatasi siswa dengan penerapan metode inkuiri berbantuan video interaktif ini siswa diberi kesempatan untuk membuat hipotesa dan memecahkan masalah selanjutnya melakukan percobaan dan mengamati, kemudian hasil pengamatannya disampaikan didepan kelas dan dievaluasi oleh guru (Roestiyah, 2012: 80).

Tujuan penelitian ini adalah untuk meningkatkan hasil belajar siswa pada mata pelajaran IPA dengan penerapan metode inkuiri berbantuan video interaktif pada siswa eklas III SD.

\section{B. METODE PENELITIAN}

Jenis penelitian yang dilakukan peneliti merupakan penelitian Tindakan Kelas atau yang sering kali disingkat dengan PTK . Penelitian Tindakan Kelas (PTK) merupakan terjemahan dari Classroom Action Research yaitu satu Action Research yang dilakukan di kelas dengan tujuan memperbaiki mutu praktik pembelajaran. Penelitian tindakan kelas ini akan dilakukan secara kolaboratif, yaitu dengan melakukan kolaborasi kerjasama antara guru kelas dengan peneliti. Penelitian dilakukan pada sejumlah 39 siswa kelas III di salah satu SDN yang berada di daerah kecamatan sidomukti Kota Salatiga.

1. Variabel Penelitian dan Definisi Operasional Variabel dalam penelitian ini tergolong menjadi dua yaitu variabel bebas dan variabel terikat.

a. Variabel Bebas (x)

Variabel bebas merupakan variabel yang menjadi pengaruh atau sebab berubahnya variabel terikat. Adapun variabel bebas mempunyai sifat dapat berdiri sendiri atau independent, variabel bebas dalam penelitian ini adalah metode Inkuiri Berbantuan Video Interaktif.

b. Variabel Terikat (Y)

Variabel terikat merupakan variabel yang menjadi akibat dari pengaruh yang diberikan oleh variabel bebas, variabel terikat dalam penelitian ini adlaah Hasil belajar siswa kelas III. Sedangkan definisi operasional sebagai berikut :

a. Metode Inkuiri berbantuan video interaktif adalah metode dimana sisswa diberi kesempatan untuk emmbuat hipotesa dan memecahkan masalah selanjutnya melakukan percobaan dan mengamati, kemudian hasil pengamatannya disampaikan didepan kelas dan dievaluasi oleh guru.

b. Hasil Belajar adalah bagian terpenting dalam pemeblajaran. Nana Sudjana (2009: 3) mengemukakan bahawa hasil belajar siswa pada hakikatnya adalah perubahan tingkah laku sebagai hasil belajar dalam pengertian yang lenih luas mencakup bidang kognitif, afektif, dan psikomotorik. Hasil belajar akan menyebabkan perubahan yang sangat mendasar bagi siswa sebagai proses perubahan.

Dalam mengumpulkan data penelitian, peneliti menggunakan dua teknik yang meliputi observasi tes dan angket.

a. Observasi

Observasi digunakan untuk mengukur aktivitas guru dan siswa selama melaksanakan pemeblajaran dengan metode inkuiri berbantuan vide interaktif. Dalam kegiatan ini, guru kelas III akan berkolaborasi dengan peneliti. Sedangkan peneliti akan bertindak membantu guru kelas III dalam mengoperasikan komputer.

b. Angket

Peneliti menggunakan teknik ini untuk mengukur hasil belajar siswa. maka dari itu, peneliti menggunakan teknik angket untuk mendapatkan data dari subyek penelitian tentang kecenderungan hasil belajar siswa setelah adanya tindakan dengan menerapkan metode inkuiri berbantuan video interaktif. 


\section{Hipotesis Tindakan}

Berdasarkan kajian teori dan kerangka berpikir di atas, maka hipotesis penelitian tindakan kelas dirumuskan sebagai di bawah ini:

a. Diduga langkah-langkah metode yang terdapat dalam metode pembelajaran inkuiri berbantuan video interaktif mampu membuat siswa lebih aktif dan senang karena adanya suasana bermain sambil belajar sehingga mampu meningkatkan hasil belajar pada mata pelajaran IPA siswa kelas III.

b. Diduga hasil belajar siswa kelas III akan meningkat jika metode inkuiri berbantuan video inetraktif diterapkan dengan ciri-ciri senang terhadap pelajaran, mempunyai kemauan keras untuk belajar, mempunyai perhatian pada saat belajar dan ketekunan dalam belajar.

\section{HASIL DAN PEMBAHASAN}

\section{Hasil Penelitian}

\section{a. Deskripsi Kondisi Awal}

Berdasarkan hasil observasi kondisi awwal penelitian ini, yang diperoleh dari wawancara terhadap guru kelas III SD, yang bertujuan untuk mengetahui hasil eblajar siswa pada mata pelajaran IPA dengan kriteria ketuntasan minimun (KKM) adalah 70. Dari 39 siswa ketuntasan hanya mecapai 46\% sebanyak 18 siswa. sementara siswa yang belum mencapai KKM adalah $54 \%$ atau 21 siswa dengan rata-rata 68 . Nilai tertinggi 88 dan terendah 54

TABEL 1

HASIL BELAJAR IPA SISWA KELAS III PADA KONDISI AWAL

\begin{tabular}{|c|c|c|}
\hline Rentang Nilai & Frekuensi & Persentase \\
\hline $80-89$ & 4 & $10 \%$ \\
\hline $70-79$ & 17 & $44 \%$ \\
\hline $60-69$ & 13 & $34 \%$ \\
\hline $50-59$ & 5 & $12 \%$ \\
\hline Jumlah & 39 & $100 \%$ \\
\hline Rata-rata & 68 & \\
\hline Nilai terendah & 54 & \\
\hline Nilai tertinggi & 88 & \\
\hline $\begin{array}{c}\text { Jumlah siswa tidak } \\
\text { tuntas }\end{array}$ & 21 & \\
\hline Jumlah siswa tuntas & 17 & \\
\hline
\end{tabular}

Setelah dilaksanakan pembelajaran selama 3 kali pertemuan, pada akhir siklus I yang dilaksanakan pada tanggal 27 maret 2018 dilakukan evaluasi untuk mengukur tingkat pemahaman siswa denga tes tertulis dalam bentuk soal pilihan ganda pada mata pelajaran IPA dengan materi kenampakan pemrukaan bumi. Data hasil belajar IPA diperoleh sebagai berikut, dari 39 siswa yang belum mencapai KKM terdapat 17 siswa (44\%) dan yang sudah mencapai KKM terdapat 22 siswa (56\%) dengan nilai terendah 40 dan nilai tertinggi 95 dan nilai rata-rata adalah 69 .
TABEL 2

HASIL BELAJAR SIKLUS I SISWA KELAS III

\begin{tabular}{|c|c|c|}
\hline Rentang Nilai & Frekuensi & Persentase \\
\hline $90-95$ & 8 & $20 \%$ \\
\hline $80-89$ & 9 & $23 \%$ \\
\hline $70-79$ & 5 & $13 \%$ \\
\hline $60-69$ & 5 & $13 \%$ \\
\hline $50-59$ & 7 & $18 \%$ \\
\hline $40-49$ & 5 & $13 \%$ \\
\hline Jumlah & 39 & $100 \%$ \\
\hline Rata-rata & 69 & \\
\hline Nilai terendah & 40 & \\
\hline Nilai tertinggi & 95 & \\
\hline $\begin{array}{c}\text { Jumlah siswa tidak } \\
\text { tuntas }\end{array}$ & 17 & \\
\hline $\begin{array}{c}\text { Jumlah siswa } \\
\text { tuntas }\end{array}$ & 22 & \\
\hline
\end{tabular}

Siklus 2 dilaksanakan 3 kali pertemuan yaitu pada tanggal 4 april 2018 bertempat disalah satu SDN kecamatan sidomukti Kota salatiga. Praktek mengajar siklus 2 ini dilaksanakan dengan KD 6.2 hubungan awan dengan kondisi cuaca . data hasil belajar IPA diperoleh sebagai berikut dari 39 siswa yang sudah mencapai KKM terdapat 32 siswa dengan persentase (82\%) sedangkan siswa yang belum mencapai KKM terdapat 7 orang dengan persentase (18\%). Dapat disajikan seperti tabel dibawah ini :

TABEL 3

HASIL BELAJAR SIKLUS II SISWA KELAS III

\begin{tabular}{|c|c|c|}
\hline Rentang Nilai & Frekuensi & Persentase \\
\hline $90-95$ & 7 & $\mathbf{1 8 \%}$ \\
\hline $80-89$ & 16 & $42 \%$ \\
\hline $70-79$ & 8 & $\mathbf{2 2} \%$ \\
\hline $60-69$ & 1 & $\mathbf{2} \%$ \\
\hline $50-59$ & 2 & $5 \%$ \\
\hline $40-49$ & 4 & $11 \%$ \\
\hline Jumlah & 39 & $100 \%$ \\
\hline Rata-rata & 72 & \\
\hline Nilai terendah & 40 & \\
\hline Nilai tertinggi & 95 & \\
\hline Jumlah siswa tidak tuntas & 7 & \\
\hline Jumlah siswa tuntas & 32 & \\
\hline
\end{tabular}

Berdasarkan tabel tersebut menunjukkan kenaikan rata-rata kelas tindakan dari semula kondisi pra siklus sebesar $44 \%$. Pada nilai rata-rata tertulis akhir siklus 2 menunjukkan terdapat 82\% atau 32 dari 39 siswa tuntas belajar, sedangkan $18 \%$ atau 7 dari 39 siswa termasuk dalam kategori tidak tuntas belajar. Hal ini berdasarkan KKM yang telah di tentukan oleh sekolah sebesar 70. Adapun rerata kelas yaitu 72. Hal tersebut sudah mencapai tujuan yang diharapkan yaitu sudah mencapai indikator keberhasilan sekurang-kurangnya 82\% siswa tuntas dan mengalami ketuntasan hasil belajar secara individual $\geq 70$ dalam pembelajaran IPA meningkat 
dengan kategori baik, sehingga dapat disimpulkan bahwa siklus II berhasil.

Pada siklus I ini pelaksanaan penelitian tindkaan kelas dengan menggunkan metode inkuiri berbantuan vide interakrif sudah meningkat secara keseluruhan sudah baik karena dalam proses pembelajaran guru mampu menguasai pembelajaran dengan mengatasi masalah-masalah yang tejadi pada siklus I . pada pembelajaran siklus 2 ini guru sudah membuat siswa fokus dalam pembelaaran dengan mmberikan tugas kepada masing-masing siswa dan siswa menyimpulkan hasil pembelajaran yang sudah dilakukan dengan cara memberikan lembar kerja kepada masing-masing siswa dan siswa menyimpulkan hasil pembelajaran secara tertulis, dengan demikian siswa benar-benar paham dengan materi yang sudah dipelajari. Selanjutnya, guru selalu memberikan motivasi dan rangsangan pada siswa berupa pertanyaan-pertanyaan sesuai dengan materi yang dipelajari sehingga tejadi kegiatan tanya ajwab antara siswa dengan guru yang membuat siswa lebih aktif dalam pembelajaran. Dalam pembelajaran guru selalu menanyakan kepada siswa tentang materi yang belum dipahami oleh siswa sehingga seluruh siswa benar-benar paham tentang materi yang dipelajari. Dengan menggunkan metode inkuiri berbantuan vide interaktif membuat hasil belajar siswa meningkat pada siklus II dibandingkan siklus I. Karena dapat dilihat dari siklus II bahwa 32 siswa kelas III SD yang berada di kecamatan sidomukti Kota Salatiga telah mencapai ketuntasan belajar yang sudah di tentukan yaitu KKM $\geq 70$. Sedangkan 7 siswa belum mencapai ketuntasan belajar yang sudah di tentukan. Akan tetapi pada siklus II ini mengalami kenaikan walaupun pelaksanaanya pada siklus II sudah baik tetapi masih beberapa masalah yang mengganggu diantaranya masih ada bebrapa siswa yang masig pasif dalam proses pemeblajaran .

Berikut ini adalah tabel hasil belajar siswa pada mata pelajaran IPA pada kondisi awal, siklus 1 dan siklus 2 yang disajikan pada tabel di bawah ini:

\section{TABEL 4}

HASIL BELAJAR PRA SIKLUS, SIKLUS I DAN SIKLUS 2 SISWA KELAS III

\begin{tabular}{|l|c|c|c|}
\hline Data Hasil Belajar & Pra Siklus & Siklus I & Siklus II \\
\hline Nilai Rata-rata & 68 & 69 & 72 \\
\hline Nilai Terendah & 54 & 40 & 40 \\
\hline Nilai Tertinggi & 88 & 95 & 95 \\
\hline Tuntas & 18 & 22 & 32 \\
\hline Tidak Tuntas & $\mathbf{2 1}$ & $\mathbf{1 7}$ & 7 \\
\hline $\begin{array}{l}\text { Persentase } \\
\text { Ketuntasan }\end{array}$ & $44 \%$ & $56 \%$ & $82 \%$ \\
\hline
\end{tabular}

Berdasarkan tabel tersebut tejadi peningkatan hasil belajar pada pra siklus, siklus I sampai siklus II. Pada pra siklus nilai rata-rata 68 , nilai terendah
54, nilai tertinggi 88, siswa yang tuntas KKM sebanyak 18 dan yang mendapatkan nilai di bawwah KKM terdapat 21 siswa dengan persentase ketuntasan $44 \%$. Pada siklus I persentase ketuntasan belajar adalah $56 \%$ namun harus dilaksanakan silus II karena belum memenuhi indikator keberhasilan dimana ketuntasab belajar baik sekurang-kurangnta adalah $80 \%$.

Pada siklusI terjadi peningkatan nilai hasil belajar dengan nilai rata-rata 69 , nilai terendah 40 , nilai tertinggi 95, siswa yang mecapai KKM terdapat 22 siswa dan yang belum mencapai kkm terdapat 17 siswa dengan persentase ketuntasan $56 \%$.

Pada siklus II ini terjadi peningkatan nilai hasil belajar yang signifikan dengan rata-rata 72 , nilai terendah 40, nilai tertinggi 95, siswa yang mencapai KKM 32, sedangkan siswa yang belum mecapai KKM terdapat 7 siswa dengan persentase ketuntasan $82 \%$.

Menurut data diatas kenaikan hasil belajar serta ketuntasan klasikal dari siklus I sampai siklus II dari 56\% menjadi $82 \%$. Terjadinya kenaikan hasil belajar siswa dikarenakan dalam tahap pembelajaran guru melakukan kegiatan secara terencana dan sistematis.

Berdasarkan indikator keberhasilan yang ditetapkan kriteria ideal ketuntasan adalah sekurang-kurangnya $80 \%$. Hal ini ditunjukkan dari ketuntasan yang dicapai hanya $56 \%$ dengan jumlah siswa yang tuntas sebanyak 22 siswa dari 39 siswa. setelah dilaksanakan siklus II menunjukkan persentase ketuntasan mencapai $82 \%$ dengan jumlah yang tuntas 32 dari 39 siswa.

Pada penelitian dengan menggunakan metode inkuiri berbantuan video interaktif tidak hanya hasil belajar sja yang meningkat, akan tetapi keaktifan dan berfikir kritias siswa juga meningkat. Sebelum dilakukan penelitian sleama mengikuti proses pembelajaran siswa kurang aktif, kurang berani mengemukakan pendapat, dan kurang antusias dalam mengikuti pembelajaran. Selain itu dalam menyampaikan materi guru belum menggunakan metode pemeblajaran yang sesuai. Akan tetapi setelah dilaksanakan pembelajaran menggunakan metode inkuiri berbantuan video interaktif ternyata dapat meningkatkan hasil belajar siswa karena metode inkuiri ini siswa di tuntut aktif untuk memecahkan masalah yang diberikan, memiliki sikap disiplin dan kegiatan kerjasama menyatukan pikiran sehingga semua siswa paham dengan materi yang dipelajari. Berdasarkan hasil penelitian yang dijelaskan diat, maka metode inkuiri berbantuan vide interaktif memberi pengaruh pada peningkatan kognitif siswa. hal ini sesuai dengan aliran kognitif yang mendefinisikan pemeblajaran sebagai cara guru memberikan kesempatan pada siswa untuk berpikir agar mengenal dan memahami sesuatu yang dipelajari (Hamdani, 2010: 23). 
Peningkatan hasil belajar dan perubahan sikap belajar yang dialami siswa merupakan kelebihan dari penerapan metode pembelajaran inkuiri Berbantuan media video interaktif Selain mempunyai kelebihan, tentu juga mempunyai kekurangan dalam penerapannya. Kekurangan tersebut dialami pada proses pembelajaran karena masih adanya siswa yang masih cenderung mencari kesibukan sendiri dan mengobrol hal-hal diluar materi saat berlangsungnya kegiatan belajar, Beberapa siswa masih kurang konsentrasi dalam mengikuti pelajaran, siswa masih pasif dalam kegiatan pembelajaraan, ada beberapa siswa yang lambat dalam menerima materi, Namun, kekurangan tersebut dapat diatasi oleh guru pada kegiatan belajar pada siklus 2 dengan cara guru membimbing siswa untuk selalu fokus dalam pembelajaran karena dalam setiap akhir pembelajaran guru memberikan tugas kepada masing-masing siswa menyimpulkan hasil pembelajaran. Selanjutnya, untuk mengatasi siswa yang masih pasif dalam kegiatan pembelajaran guru selalu memberikan rangasangan berupa pertanyaan kepada siswa sehingga siswa dapat merespon rangsangan yang diberikan oleh guru sehingga siswa menjadi lebih aktif dalam pembelajaran..dengan menggunakan media Video Interaktif siswa lebih mudah dalam belajar karena informasi-informasi yang didapatkan dicatat dengan berdasarkan pemetaan pikiran-pikiran sehingga siswa lebih mudah dalam mempelajari kembali materi yang sudah dapatkan. Pada penggunaan media Video Intreaktif siswa harus sekreatif mungkin dalam mencatat informasi yang baru didapatkan. Penulisan dengan Audiovisual pemetaan-pemetaan pikiran harus jelas dan menarik, semakin jelas dalam memetakan pikiran maka semakin mudah untuk dipahami, maka dari itu siswa lebih mudah untuk memahami sehingga siswa paham dengan materi baru yang disampaikan, hal itu berdampak pada hasil belajar siswa menjadi lebih baik. Pada peningkatan siklus 2 masih terdapat 7 siswa yang belum lulus KKM, hal itu disebabkan siswa tersebut lambat dalam menerima materi belajar sehingga kedua siswa tersebut perlu adanya bimbingan khusus dalam memberikan materi pembelajaran. Solusi untuk mengatasi siswa yang lambat dalam menerima pelajaran adalah: guru selalu bertanya tentang materi yang belum dipahami siswa dalam setiap langkah pembelajaran, memberikan perlakuan khusus kepada siswa tersebut, siswa yang lambat dalam menerima pelajaran dikumpulkan menjadi satu deret tempat duduk. Dengan seperti itu setiap akhir penyampaian materi guru menjelaskan kembali pada siswa-siswa yang lambat dalam menerima materi yang sudah tergabung menjadi
satu.Guru juga mudah dalam mengontrol siswa yang belum benar-benar paham dengan materi tersebut.

Berdasarkan pembahasan dan penjelasan mengenai metodeinkuiri berbantuanvideo interaktif, penulis merumuskan implikasi penelitian seperti di bawah ini:

\section{Implikasi Penelitian}

Implikasi penelitian ini yaitu adanya peningkatan kualitas pembelajaran IPA yang meliputi keterampilan guru, aktivitas siswa, dan hasil belajar menggunakan metodeinkuiri berbantuan video interaktif pada siswa kelas III SDN yang berada di kecamatan sidomukti Kota Salatiga. Yang meliputi implikasi teoritis, praktis dan paedagogis.

\section{a. Implikasi Teoristis}

Secara teoritis implikasi dari penelitian ini yaitu keterkaitan antara hasil penelitian dengan teoriteori yang digunakan oleh peneliti. Penelitian ini membuka wawasan bagi guru terhadap metode inkuiri berbantuan video interaktif mampu meningkatkan keterampilan guru dalam mengajar terutama dalam hal meningkatkan hasil belajar dan memfasilitasi siswa dalam melakukan penyelidikan. Hal ini sesuai dengan pendapat Sutikno (2010) bahwa kedudukan guru mempunyai arti penting dalam pendidikan mengingat tugas serta tanggung jawab mencerdaskan siswanya.

Dalam penelitian ini membuktikan bahwa penerapan metodeinkuiri berbantuan vide interaktif dalam pembelajaran IPA dapat meningkatkan kualitas pembelajaran yang meliputi: keterampilan guru, aktivitas siswa, dan hasil belajar.

\section{b. Implikasi Praktis}

Implikasi praktis dalam penelitian ini berkaitan dengan hasil penelitian terhadap proses pelaksanaan pembelajaran. Penerapan metode inkuiri berbantuanvideo interaktif dalam pembelajaran IPA dibuat menarik dengan menggunakan vide interaktif yang dapat dikaitkan dengan situasi dunia nyata siswa agar dapat membantu siswa dalam proses pembelajaran.

Penerapan metode inkuiri berbantuanvide interaktif dalam pembelajaran IPA membantu guru dalam meningkatkan proses pembelajaran di kelas, selain itu dapat meningkatkan keterampilan dasar mengajar guru. Setelah diberi pembelajaran IPA dengan menerapakan metode inkuiri berbantuan vide interaktif, siswa menjadi lebih aktif, dan guru selalu mendorong siswa untuk berlatih berpikir kritis, dengan tindakan tersebut dapat meningkatkan hasil belajar siswa, sehingga metode inkuiri berbantuan media video interaktif cocok untuk diterapkan di SD khususnya kelas tinggi karena dapat melatih keterampilan berpikir siswa.

Berdasarkan pengamatan selama proses pembelajaran, didapatkan hasil bahwa 
keterampilan guru mengalami peningkatan pada setiap siklusnya. Hal tersebut dapat dilihat dari tabel pada tiap siklusnya. Pada siklus 1 skor keterampilan guru diperoleh hasil $58,8 \%$ dengan kategori baik. Pada siklus II mengalami peningkatan menjadi $76,4 \%$ dengan kategori sangat baik. Berdasarkan pengamatan aktivitas siswa selama proses pembelajaran juga mengalami peningkatan pada setiap siklusnya. Hal tersebut dapat dilihat dari tabel pengamatan aktivitas siswa. Siklus I skor perolehan 46,1 dengan kategori baik, pada siklus II meningkat menjadi 69,2 dengan kategori baik. Berdasarkan hasil tes pada setiap siklusnya. Pada siklus I diperoleh nilai rata-rata 68 dengan ketuntasan belajar klasikal 54\%, pada siklus II diperoleh rata-rata 72 dengan ketuntasan belajar klasikal 82\%.

Berdasarkan hal tersebut, penelitian ini dapat dijadikan salah satu referensi dan alternative pilihan bagi guru yang ingin menggunakan metode inkuiri berbantuan video interaktif dalam melaksanakan pembelajaran pada mata pelajaran yang lain sehingga keterampilan guru, minat belajar siswa, dan hasil belajar siswa meningkat.

\section{c. Implikasi Pedagogis}

Implikasi paedagogis dalam penelitian ini merupakan keterkaitan antara hasil penelitian dengan implikasi sebagai guru.Dengan menerapkan metode inkuiri berbantuan video interaktif dapat meningkatkan profesionalisme guru menciptakan pembelajaran inovatif, kreatif, menyenangkan sehingga kualitasnya dapat meningkat. Guru dilatih bersikap kreatif, berpikir kritis menyediakan media ataupun alat peraga menarik sesuai materi untuk membangun pengetahuan serta pertanyaan bersifat kritis untuk mengembangkan rasa ingin tahu siswa. Melalui kegiatan inkuiri, masyarakat belajar, pemodelan, guru bertindak sebagai fasilitator serta motivator yang membimbing siswa belajar secara mandiri untuk mencari, menemukan pengetahuan baru berdasarkan pengamatan atau percobaan, menanamkan rasa kerjasama, tanggung jawab, saling membantu, menghargai pendapat antar siswa, menumbuhkan rasa percaya diri, serta semangat belajar. Selain itu, guru dapat melakukan penilaian terhadap proses dan hasil sehingga tujuan pembelajaran dapat tercapai secara optimal.

Dengan demikian dapat disimpulkan bahwa metode inkuiri berbantuan video interaktif dalam pembelajaran IPA pada siswa kelas III SDdapat digunakan sebagai solusi bagi para pendidik dalam peran mengajar dibuktikan dengan penelitian ini telah mampu memberikan kontribusi positif bagi peningkatan keterampilan guru, kegiatan belajar siswa, dan hasil belajar

\section{SIMPULAN DAN SARAN}

Berdasarkan hail penelitian dan pembahasan yang telah dilakukan, dapat ditarik kesimpulan bahwa peningkatan hasil belajar IPA melalui penerapan metode inkuiri berbantuan vidoe inteaktif dapat meningkat. Oleh karena itu penulis menyarankan:

1. Pihak sekolah siharapkan bisa dijaikan masukan atau contoh bagi skeolah supaya dapat menerapkan pembelajaran yang kreatif, inovatif, dan menarik sehingga kedepan guru dapat menerapkan pemeblajaran dengan lebih menarik.

2. Bagi guru dapat dijadikan refrensi dalam memilih metode pembelajaran yang sesuai dengan karakteristik mata pelajaran dan karakteristik siswa.

\section{UCAPAN TERIMA KASIH}

Penulis mengucapkan terima kasih kepada semua pihak yang telah membantu dalam proses penelitian, khususnya guru dan siswa kelas III SD yang berada di kecamatan sidomukti Kota Salatiga.

\section{DAFTAR RUJUKAN}

[1] Aly, Abdullah dan Eny Rahma. 2008. Ilmu Alamiah Dasar. Jakarta: Bumi Aksara.

[2] Depdiknas. 2006. Kurikulum Tingkat Satuan Pendidikan . Jakarta.

[3] Hardini, Isriani, dan Dewi Puspitasari. 2012. Strategi Pembelajaran Terpadu (Teori, Konse, Implementasi). Yogyakarta: Familia (Grouop Relasi Inti Media)

[4] Sagala, S. 2011. Konsep dan Makna Pembelajaran. Bandung. ALFABETA.

[5] Mulyasa, E. 2008. Menjadi Guru Profesional (Menciptakan Pembelajaran Aktif dan Menyenangkan). Bandung: Rosdakarya.

[6] Roestyah, NK. 2001. Metode Pembelajaran. Jakarta: Gramedia

[7] Sadiman, Arief S. DKK. 2006. Media Pendidikan, Pengertian, Pengembangan dan Pemanfaatan. Jakarta: Pustekom Dikbud.

[8] Sudjana, Nana. 2009. Penilaian Hasil Proses Belajar Mengajar. Bandung: Remaja Rosdakarya.

[9] Sulistyorini, Sri. 2007. Pembelajaran IPA Sekolah Dasar. Semarang: Tiara wacana

[10] Supridjono, Agus. 2012. Metode dan model-model Mengajar. Bandung: Alfabeta

[11] Susanto, Ahmad. 2013. Teori Belajar dan Pembelajaran di sekolah Dasar. Jakarta: Kencana Prenada Media Group.

[12] Trianto. 2007. Model-Model Pembelajaran Inovatif Berorientasi Kontruktivistik. Jakarta: Prestasi Pustaka

[13] Wardani, Naniek Sulistya. 2012. Pengaruh Pendidikan Karakter pada Pembelajaran Tematik. Salatiga: Universitas Kristen Satya Wacana. 


\section{PROFIL PENULIS}

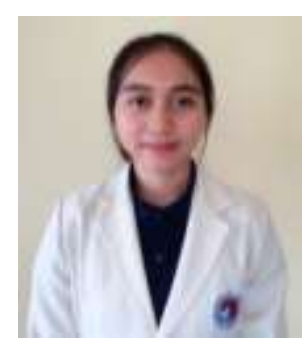

Penulis bernama lengkap "CAHYA MURTININGSIH”. Lahir di Kabupaten semarang 10 November 1995. Penulis adalah 2 bersaduara. Pendidikan sekolah dasar dimulai dari SD Negeri Rogomulyo 01 pada tahun 2000-2007. Melanjutkan di Sekolah Menengah Pertama di SMPN 01 Kaliwungu. Dan melanjutkan Sekolah Menengah Atas di SMAN 2 Boyolali. Kemudian penulis melanjutkan studi ke Perguruan tinggi Universitas Kristen Satya Wacana Salatiga FKIP PGSD pada Tahun 2013. Kritik, saran, maupun hal-hal yang berkaitan dengan kelanjutan dan pengembangan dari hasil pebelitian ini bisa dikirim ke email penulis di. cahyamurti10@gmail.com 